Ливија Д. ЕКМЕЧИЋ*

Универзитет у Стразбуру

Филолошки факултет
Оригинални научни рад

Примљен: 6. 2. 2021.

Прихваћен: 25. 2. 2021.

\title{
УТИЦАЈ ДРАМСКЕ ФОРМЕ ЕЖЕНА ЈОНЕСКА НА ДРАМСКУ ФОРМУ У ДЕЛУ АЛЕКСАНДРА ПОПОВИЋА
}

\begin{abstract}
У овом раду осветљен је начин на који су Ежен Јонеско и Александар Поповић конституисали особене драмске форме у првој фази свог стваралаштва. Такође, у истраживању се прецизно осветљавају интертекстуални односи француског и српског писца, указујући на то у којим сегментима драмскога текста и на који начин је Ежен Јонеско утицао на драмско дело Александра Поповића. Тежиште истраживања стављно је на драмски жанр и драмски дијалог, док се код драмског времена указује на кључну заједничку тачку два писца по којима проток времена нема никакав значај за драмску радњу, а самим тим ни за драмски свет који се јавља у делима ових писаца.

Кључне речи: Ежен Јонеско, Александар Поповић, интертекстуалност, драмска форма, жанр, драмски језик.
\end{abstract}

Ежен Јонеско и Александар Поповић представљају два веома особена драмска писца првенствено по драмској форми коју срећемо у њиховим делима, као и по начину на који употребљавају традиционални жанр - фарсу. Међутим, значајну нетипичност у делима писаца о којима је овде реч представља и драмски језик у коме се уочава необичан спој различитих типова реплика, односно различитих дијалошких форми. Поред тога ови писци на специфчан начин приказују јунаке изникле на подлози конкретних друштвених средина, те док Јонеско за прототип узима грађанску класу, Поповић своју пажњу усмерава на послератну периферију Београда. Код писца о којима је у овом истраживању реч важно је обратити пажњу и на то да они у својим драмским делима стварају драмске ситуације и драмске радње које су често веома удаљене од аристотеловске поетике ${ }^{1}$.

\footnotetext{
*livijaekmecic@yahoo.com

${ }^{1}$ О Јонесковом удаљавању од аристотеловске поетике писао је Емануел Жакар, који том приликом наводи да Јонеско „не признаје 'аристотеловски’ принцип узрочности” (Жакар 1981: 472).
} 
Поред заједничких особености драмских дела два писца, и време њиховог појављивања у књижевности допушта нам да говоримо о књижевном утицају дела Ежена Јонеска на дело Александра Поповића. Утицај Јонеска на Поповића може се објаснити најпре потребом за новим формама, као и потребом за апсурдом који руши све што је традиционално, а та потреба, како је то готово увек случај са драмском књижевном врстом, долази из дневно-друштвених подстицаја. С друге стране, утицај о коме је реч могао је бити и подстакнут околностима у којима су се дела Бекета и Јонеска већ педесетих година играла у београдском позоришту. Наиме, у Атељеу 212 изводе се комади писца, који ће значајно обележити историју драмске књижевности двадесетога века, од којих Јонеско постаје нашој поблици ближи.

У настојању да осветлимо утицај драмске форме Ежена Јонеска на драмску форму Александра Поповића, узели смо за анализу драме из прве фазе рада оба писца. Односно, код Ежена Јонеска ограничили смо се на три драме које су биле у београдским позориштима на сцени крајем педесетих: „Ћелава певачица”, „Лекција” и „Столице”, а код Алекстандра Поповића на драме које је створио почетком шездесетих, односно које излазе на сцену 1964. и 1965, а то су: „љубинко и Десанка”, „Чарапа од сто петљи” и „Сабља димискија". У овој, почетној, фази два писца су најсличнија и утицај Јонеска на Поповића видљив је на свим нивоима драмскога текста. То се може разумети и из чињенице да су и француски и српски писац у својој првој фази стваралаштва заиста и крајње оригинални у односу на драмска дела која су пре њиховог појављивања образовала историјску раван драмске књижевности.

Настојећи да разумемо на који начин писци о којима је реч компонују своју необичну драмску форму, анализирали смо неколико драмских компоненти, почевши од драмског жанра.

Јонеско је био свестан значаја драмскога жанра, а видећемо касније и Поповић. У „Белешкама и контра-белешкама” Јонеско је оставио важне записе везане за питања драмске форме, жанра, драмског језика и своје целокупне драматургије. Он је и сам указао на оне елементе својих драмских текстова без којих није могуће разумети Јонесково стваралаштво. У белешкама француски аутор указује на то да жели да створи чисто позориште. А стварајући такво позориште он полази од контраста који често подразумева спој трагичног и комичног. Заправо, француски писац сматра да нема велике разлике између комичног и трагичног, указујући на то да, по њему, комедија не нуди никакв излаз (1966: 61). На више места говори о томе да је и сам своје комаде именовао као „анти-комад”, „трагична драма”, „псеудо-драма”, „трагична фарса”, управо јер му се чинило да је „комедија трагедија” али и обрнуто (в. Јонеско 1966: 61).

За кловновску интерпретацију (в. Јонеско 1966: 60-61) дате ситуације, односно за позориште поруге, како Е. Жакар именује Јонескову драму (Жакар 1981: 471-497) Јонеско узима жанровске оквире једног традиционалног драмског жанра, а то је фарса. Исти жанр, на који и сам писац указује, наћи ћемо и код Поповића. Настојећи да одбаци сваку врсту и традиционалног и модерног позоришта, Јонеско у темељ своје драме поставља игру, и на тај 
начин он се враћа свом идеалу - чистом позоришту. С друге стране, и код Поповића у основи, како је на то скренула пажњу Мирјана Миочиновић (в. 1975: 95-123) стоји игра. Јонескова игра, али и Поповићева у његовим раним радовима, има своју специфичност, она је, како то каже Јонеско, „безразложна игра", односно, покретач игре и код Јонеска и код Поповића изостаје. Игра, односно драмска радња, почиње без видљиве мотивације, а завршава се без конкретне финалне сцене, што је изузетно значајно за њихову драмску форму.

Да би на сцену поставили игру, оба писца, бирају жанр који има вишевековну традицију, фарсу. Зашто им је управо овај жанр био привлачан, може се разумети на основу карактеристика фарсе на које указује најпре Тома Себије (Thomas Sebillet), француски критичар, а то су „слобода, смех и недостатак форме" (Себије 1910: 165). Међутим, на избор фарсе утицао је и свет који желе да прикажу француски и српски писац, али и потреба да се створи особена драматургија. Наиме, у драмама које су предмет наше анализе код Јонеска, али и код Поповића приметан је необичан начин компоновања драмске радње, која у драмама о којима је овде реч није ни драмска радња настала на традиционалан начин ни драмска радња обликова у Чеховљевском маниру. Оба писца једноставно приказују један исечак из живота јунака који су потпуно дехуманизовани, а који представљају, с једне стране, просечно грађанство, а с друге стране, маргинално друштво идеологије комунизма (градска периферија). Међутим, тренутак који те драме приказују није нимало посебан у односу на било који други тренутак из живота јунака². За приказивање оваквог типа драмске радње фарса се показује као плодно тле, јер им она омогућава да на сцену изведу просечан дан јунака који ни по чему није изузетан.

Према теоријским освртима Џесике Дејвс „фарса одлучно одбацује законе стандардне рационалности и озбиљности, има извесну парадоксалну вредност. Фарса садржи ноту неразумности која, истини за вољу, представља важан елемент људске природе. Од Светковине луда до браће Маркс, фарса омогућава уживање у препуштању радостима и ужасима бесмислица" (Дејвс 2015: 337). А кључна одлика фарсе која је имала посебно место у Јонесковим и Поповићевим драмским делима, јесте управо оно на шта указује Гуревич: „Подвизи фарсе не одају почаст достигнућима људског разума; уместо тога, оне бележе животворно противљење строгој владавини разума - и свим другим тегобним захтевима цивилизације” (М. Гуревич цитирано према Дејвс 2015: 337). Дакле, када имамо на уму елементе фарсе и њене могућности које наводе Дејвсова и Гуревич, постаје сасвим видно да су писци веома пажљиво и промишњено одабрали жанр својих драмских дела. Због тога, код Јонеска и Поповића, у првој фази њиховог рада, постоји доследно чиста форма уместо жанровског синкретизма, карактеристичног за драмска дела периода у којем настају њихове драме.

\footnotetext{
${ }^{2}$ Иако нам се у „Лекцији” може учинити да финални догађај који је приказан, не припада свакодневици, он ипак чини свакодневицу у Професовом животу.
} 
У контексту Јонесковог промишљања чистог позоришта, и преплитања комичног и трагичног, као и у контексту теоријских проучавања фарсе, могу се сасвим прецизно разумети жанровска одређења која ови писци пишу уз своја дела. Француски класик драму „һелава певачица” одређује као антикомад, „Лекцију” као комичну драму, а драму „Столице” сасвим конкретно као трагичну фарсу, док, Александар Поповић свој првенац означава као фарсу и no, „Чарапу од сто петљи” као фарсу in memoriam, а дело „Сабља димискија” као горчу фарсу у једном чину. Иако је српски писац конкретнији, видно је да се код оба аутора ради о фарси, на шта је уосталом за своја дела Јонеско био експлицитан у „Белешкама и контра-белешкама”.

Други важан елемент за разумевање специфичне Јонескове и Поповићеве драмске форме представља драмски језик. Наиме, Јонеско је у „Белешкама и контра-белешкама" поклонио доста пажње драмском језику, указујући на то да је управо овај елемент кључан код драмскога дела, јер он мора да се разликује од језика у другим уметничким делима, а нарочито од језика као средства комуникације. Пишући о театру, Јонеско наглашава, на пример, код Пирандела, да су управо његов драмски језик и „чист театарски инстинкт” оно што италијанског писца и данас чини живим (в. Јонеско 1966: 56). По Јонеску, театар има посебан начин употребе говора, а то је дијалог у коме мора постојати конфликт (в. Јонеско 1966: 63). И заиста када се анализира језик у драмама Ежена Јонеска и Александра Поповића уочава се да је употреба језика веома сложена и да језик чврсто почива на два принципа на којима Јонеско инсистира, а она су конфликт и антагонизам, за који француски писац наводи да је основа театра јер позориште не може да постоји осим ако је чврсто поникло на овоме принципу (в. Јонеско 1966: 62) ${ }^{3}$.

Уз остварење дијалога на принципу антагонизма, Јонесков, а нарочито Поповићев дијалог имају и снажан музички елемент, као важну компоненту драмског језика. Наиме, оба писца у драмском дијалогу настоје да остваре одређени ритам. И како драмска радња одмиче тај ритам је све бржи, да би у Јонесковој „Ђелавој певачици” и Поповићевој „Сабљи димискији” добио такво убрзање којим се остварује ситуација у којој једино ритам постаје важан у дијалогу али не и оно што протагонисти изговарају. Тако се Јонескова „Ћелава певачица” завршава сценом у којој сви говоре у глас све брже и брже, изговарајући речи без икаквог значења, изговарајући само слова или само делове речи: „Г. Мартин: Марица, лонца трица. / Гђа Смит: Кришнамурти, Кришнамурти, Кришнамурти! / Г. Смит: Папа ће да скапа! Папа нема капу, капа има папу. / Гђа Мартин: Базар, Балзак, Базен. / Г. Мартин: Бизарно, брзина, образина. / Г. Смит: А, е, и, о, у, а, е, и, о, у, а, е, и, о, у. / Гђа Мартин: Бе, це, де, еф, ге, ел, ем, ен, пе, ер, ес, те, ве, ве, икс, цет. / Гђа Мартин: Лук и вода, млеко с луком. / Гђа Смит продужава воз: Теф, теф, теф, теф, теф, теф, теф, теф, теф, теф. / Г. Смит: Није / Гђа Мартин: то / Г. Мартин: О - / Гђа Смит: -нуда / Г. Смит: Већ / Гђа Мартин: је / Г. Мартин: О - Гђа Смит: -вуда.

\footnotetext{
${ }^{3}$ „[...] il n’y a de théâtre que s'il y a des antagonismes” (Јонеско 1966: 62).
} 
/ Сви заједно, на врхуниу беса урлају једно другом у уши. Светлост се гаси. У мраку се чује све бржим ритмом" (Јонеско 1997: 99).

С друге стране, Поповићев ритам у „Сабљи димискији” образован је током читаве радње или посредством дијалога или кроз сонгове који се појављују на сцени с времена на време. Сонгови, које пева коло девојака што има призвук хора из античке драме, имају конкретну улогу успоравања драмске радње јер за време тих сонгова оно што се приказује на сцени потпуно се зауставља. На тај начин Поповић заправо постиже спорији ритам драмске радње. Ипак, на крају драме „Сабља димискија” сусреће се ритам остварен кроз говор јунака по истом принципу као код Јонеска. С тим што се код Јонеска у „Ћелавој певачици” ритам убрзава до пароксизма, како на то указује Жакар (Жакар 1981: 487), а код Поповића се постиже одређени ритам који све што је приказано на сцени утапа у једну специфичну демагогију. „Рада (брзо димискију врати у корице и скочи бесно на сто): Шта је, бре, Срби!... већ ропћете!... нисам још честито ни засео, а ви бисте ме већ свргли?!... (Сви присутни нешто неразговетно мрмљју и брундају у хору. Рада повиси тон.) Аух, колико је муштерија да ми се ували код жене у кревет!!... (Сви присутни мрмљају.) Па три атентата!!... Шест препада!!... Седамнаест преврата!!... и све, за једну ноћ?!... (Из билијар сале неко закмечи као беба: Кмеееее!...) И кад ти пре, жено, роди, нисмо још ни ноге честито помешали?!... (Сви присутни мрмљају.) Е, тасте, па ако си ми својта, мање кради!... ко ће теби надавати?!... (Сви присутни мрмљају.) Мирно, кад говорим!!! (Сви умукну.) Хе, за вас је дурунга једини светац, свеца ли вам лоповског!!! (Скочи са стола и мариира ситним корацима.) За мном!... (Сви се тискају иза юега.) Ја ћу вас!... А ко ће коме, коิ свој своме!... Напред!... лева!... лева!!... лева!!!... (Одлазе уз Распопову песму уз хармонијум.) Одосмо сад све улево!...” (Поповић 2001: 192-193). Ипак, Поповићев завршетак је сложенији него код Јонескове „Ћелаве певачице”. Док француски писац својим ритмом остварује на сцени осећај општег безнађа у коме влада апсурд, Поповић кроз остварени ритам конституише слику морала друштвене групе која је на сцени, а у којој су такође безизлазност и апсурд веома присутни.

И у драмама „Лекција”, „Столице”, „љубинко и Десанка” и „Чарапа од сто петљи" писци посредством убрзавања дијалога или специфичним понављањима остварују ритам драмскога дела, односно остварују ритам самога драмског језика. Понављања путем којих се у неким драмама обликује ритам служе писцима и као одређени тип антиципације, какав је случај у Јонесковој драми „Лекција” где је реч бол која се ритмично понавља антиципација трагичног краја Ученице, коју ће на крају драмске радње Професор силовати и убити.

Нарочиту особеност драмског језика код Јонеска и Поповића представља начин на који се конституише драмски дијалог. Драмски дијалог онеобичава се на два начина. Најпре, посредством драмског поступка који се среће и код других драмских писаца, којима је традиционална драматургија ближа, а то је укрштањем различитих монолога у дијалог. Ситуације у којима оно што јунаци говоре и начин на који говоре одаје утисак да свако изговара 
свој монолог, који је једноставно сложен у привидни дијалог, нису ретке. То значи да између ликова на сцени нема стварне интеракције, него је дат привид да се дијалог остварује између два лика („Ћелава певачица” и „Лекција”, односно „Љубинко и Десанка” и „Чарапа од сто петљи”), или између више ликова („Ћелава певачица”, „Чарапа од сто петљи” и „Сабља димискија”). ${ }^{4}$ Други вид онеобичавања дијалога, који је заиста важна карактеристика писаца о којима је реч остварује се кроз измештање уобичајених функција референцијалним, фатичким и конативним репликама ${ }^{5}$. Овај драмски поступак је веома сложен и њиме се често сугеришу стварни односи међу ликовима, као и тип драмског света у Јонесковим и Поповићевим драмама.

Како функционишу ова два типа онеобичавања драмскога језика, може се најлакше уочити у иницијалним драмским ситуацијама драма „һелава певачица” и „љубинко и Десанка”. У Јонесковој „Ћелавој певачици” иницијална драмска ситуација је једно уобичајено вече мужа и жене, господина и госпође Смит, а реплике које они измењују најпре стварају дијалошку ситуацију, у којој је видно како је заправо реч о два монолога у којима је доминантно одсуство интеракције међу ликовима. Потом дијалог постаје чвршћи, али се функција реплика измењује на тај начин да дијалог карактерише одсуство информација, што је битно на пољу карактеризације јунака. На самом почетку ситуациони апсурд је огољен јер се госпођа Смит обраћа свом мужу који је и сам био присутан вечери о којој она говори. „Гђа Смит: Гле девет часова. Вечерали смо чорбу, рибу, кромпир са сланином, енглеску салату. Деца су пила енглеску воду. Добро смо вечерали вечерас зато што станујемо у околини Лондона и што се зовемо Смит" (Јонеско 1997: 81). Међутим, овде прерастање референцијалне реплике у фатичку има особено значење. Овим поступком Јонеско на сцени приказује одсуство стварне комуникације између чланова типичне грађанске породице.

У иницијалној ситуацији Поповићеве драме „љубинко и Десанка” такође се може уочити стопљеност референцијалне и фатичке реплике. Њихове функције не само да се преплићу, него у неким тренуцима фатичка, али и референцијална функција бивају доведене до апсурда. „Извините, госпођице, знате ли ви неког доброг сајџију овде у близини? Ви мислите да се ја зафркавам? (Приђе јој ближе и ставља јој иепни сат на уво. Она се тргне и одмакне главу.) Слободно, слободно... (Поново јој стави сат на уво.) Стао, је л’ да?.. А које је доба? / Десанка: Четри и фртаљ. / Љубинко: Тако рано, а већ се разданило?! / Десанка: Па ово је подне, забога није јутро! / Љубинко: Како сам се, за толико пребацио?! Онда могу и да поседим... Ако ме ви примате у друштво? [...] Да ја вама нисам на сметњи?” (Поповић 2001: 18).

\footnotetext{
${ }^{4}$ „Столице” имају специфичну дијалошку ситацију која је знатно обележена тиме што у дијалогу постоје ликови о којима се говори са подразумеваним њиховим присуством на сцени, а они заправо не постоје.

${ }^{5}$ Доминантна улога фатичких реплика је преношење информације. Конативним репликама се од саговорника очекује вербална или стварна акција, а фатичке реплике имају функцију започињања и одржавања дијалога, оне не преносе информације, али су стилски врло маркиране (в. Катанић-Бакаршић 2013: 73-82).
} 
Значајно је за разумевање драмскога текста и код Јонеска и код Поповића имати у виду да поједине фатичке реплике преносе реципијенту значајну информацију везану за карактер драмских јунака. Најпре управо посредством овог типа реплика обликује се драмски свет који за подтекст има конкретну друштвену групу, што и није необично с обзиром на карактер фатичких реплика. Међутим, код писаца о којима је овде реч фатичке реплике могу пренети и важне информације за драмску радњу, као што је случај у Поповићевој драми, где се управо на основу овог типа реплика уочава Љубинкова конкретна заинтересованост за Десанку. Током даље драмске радње исти тип реплика разоткриће да и Десанка има сасвим конкретне намере када је реч о Љубинку, као и да њено невешто скривање тих намера није случајно, него представља пажљиво осмишљену стратегију завођења Љубинка.

Исту технику измештања функција реплика уочавамо и у Јонесковим драмама „Лекција” и „Столице”, односно код Поповића у драмама „Сабља димискија” и ,Чарапа од сто петљи”. Посебно је занимљив начин на који Јонеско користи конативне реплике у драми „Столице”. Употреба ових реплика, с једне стране, доводи до крајњег апсурада драмски дијалог, а с друге стране, конативне реплеке осликавају психичко стање драмских ликова. Наиме, реч је о два начина онеобичавања конативне функције дијалога, односно о стављању конативних реплика у контекст који сасвим излази из логичке употребе оваквих реплика. Један од начина измештења употребе илуструје ситуација с почетка драмске радње: „Старац: Попиј свој чај, Семирамидо! / (Разуме се нема чаја) / Старица: Хајде изигравај месец фебруар" (Јонеско 1997: 202). Такође, и сви они примери употребе конативних реплика код којих заправо потпуно изостаје одговор на реплику у драми „Столице” представљају померање употребе конативних реплика ка крајњем апсурду. Таква су и обраћања невидљивим гостима типа изволите ући, изволите, седите итд, на које је немогуће добити одговор.

Међутим, у драми „Столице” Јонеско се на још један начин игра овим типом репликама, односно конативном функцијом дијалога: „Старица (Гоcnoђи): Ви нисте као данашња младеж! / Старац (с муком се сагиње да подигне невидљиви предмет, који је невидљива дама испустила): пустите, не узнемиравајте се... ја ћу га дићи... о, били сте бржи од мене... (Јонеско 1997: 207). Наиме, оваквом употребом конативних реплика у драми „Столице” обликује се специфична група драмских јунака. Ови јунаци необични су по томе што се стварају само у оквирима дијалога Старца и Старице и који једино у драмском дијалогу и постоје. Њихов статус као dramatis personae веома је комплексан. Остаје отворено питање постоје ли они као dramatis personae или не. Овде није реч о ликовима који ван сцене, на пример, утичу на драмску радњу, где је то питање теорија драме јасно разрешила (в. Пфистер 1998: 245-246), него управо о ликовима који немају никакав утицај на драмску радњу, који не постоје за реципијента, али који постоје за Старца и Старицу и који се, што је веома значајно за њихов статус, налазе у попису ликова, где су наведени као „и много других лица”. Они се не представљају на сцени реципијенту те по томе нису dramatis personae, али за Старца и Старицу они постоје и на 
сцени, потом на основу конативних реплика, видимо да ови ликови утичу на кретање Старца и Старице, што отвара питање њиховог места у односу на ону скупину ликова који су недвосмислено dramatis personae. Игра коју Јонеско ствара увођењем невидљивих ликова, њихово позиционирање у драмском делу остварено посредством конативних и референцијалних реплика значајно је померање како у оквиру језика драмскога дела, тако и у оквиру драмских јунака.

За разумевање драмске форме карактеристичне за Јонеска и Поповића, значајно је и то што у драмама, које су предмет наше анализе, изостаје драмски заплет, а драмски догађај, ако га има, он је веома специфичне природе. Таква је финална ситуација самоубиство Старца и Старице из драме „Столице", која има нешто од природе драмскога догађаја јер зауставља драмску радњу, односно прекида је у потпуности. Она такође прекида и постојање како драмских јунака Старца и Старице, тако и свих оних ликова који су конституисани једино дијалогом између ова два јунака. Самоубиство у драми „Столице” има и нешто од природе драмске ситуације и нешто од природе драмскога догађаја. С друге стране, у драми „Лекција” силовање и убиство ученице драмска је ситуација после које се не мења ништа у току драмске радње. У структуру драмскога текста постављена је на специфичан начин и долази на место кулминације радње. Таква је и појава венчања у Поповићевој драми „Сабља димискија”. Венчање, које такође долази када је ритам радње већ веома убрзан и када је безразложна свађа на врхунцу, не значи ништа за драмску радњу. Дакле, питање драмског догађаја код Јонеска и Поповића наводи на закључак да се код ових писаца ретко може говорити о драмском догађају, јер су ретке ситуације на које се може указати као на оне које мењају ток драмске радње.

У делима Ежена Јонеска и Александра Поповића могуће је такође говорити о кружној и линеарној драмској радњи. Такав је случај са Јонесковом драмом „Ћелава певачица”, која се завршава како је и почела, само се драмски пар мења: „Г. и гђа. Мартин седе као Смитови на почетку комада. Комад као да опет започиње са Мартиновима, који говоре тачно исте реплике као Смитови у првој сцени, док завеса полако пада" (Јонеско 1997: 100). Код Поповића уочавамо сличну појаву у драми „Љубинко и Десанка”, с тим што је на почетку драме Љубинко тај који долази, а на крају Десанка одлази. Код других драмских текстова, који су предмет наше анализе, финална ситуација није ни на који начин понављање иницијалне, те се не може говорити о кружној драмској радњи. Међутим, без обзира на то да ли је радња кружна или линеарна, и Јонескови и Поповићеви комади приказују кретање од појединачног ка општем, у ком се радња креће ка општем бесмислу. Анализирајући Јонескове драме, Жакар закључује да „[...] јонесковски комад обично започиње неком аномалијом а завршава се најпотпунијом фантастиком, отуд развој од појединачног смисла ка општем бесмислу, био он привидан или стваран” (Жакар 1981: 478). Исто се може рећи и за Поповићева драмска дела, што је нарочито уочљиво код драма „Чарапа од сто петљи” и „Сабља димискија”. Кретање од појединачног ка општем, односно, приказивање кроз 
индивидуално онога што је опште, а што је често обојено апсурдом, значајна је заједничка карактеристика француског и српског писца.

У оквиру драмске форме ових писаца може се говорити и о специфичној употреби драмског времена. Драмско време је увек у функцији апсурда, без обзира на то да ли је тај апсурд видан на први поглед, као у Јонесковој драми „Ћелава певачица” или не. У драми „Ћелава певачица” сусрећемо се са потпуно необичним показатељем времена: „Ватрогасац: А овај сат? / Г. Смит: Не ради добро. Воли да је у опозицији. Увек показује супртно од времена које треба” (Јонеско 1997: 95); „Сат откуцава седам пута. Тишина. Сат откуцава три пута. Тишина. Сат не откуцава ниједанпут” (Јонеско 1997: 95). Такође у дијалогу јунака, само време је релативизирано до крајњег апсурда: „Г. Смит: Умро је пре две године. Сећаш се да смо били на погребу пре годину и по. [...] Има већ три године од како се говорило о његовој смрти" (Јонеско 1997: 82). Код Поповића игра временом је нешто суптилнија у драми „Љубинко и Десанка”: „Љубинко: А које ли је доба? / Десанка: Четири и фртаљ. / Љубинко: Тако рано, а већ се разданило?! / Десанка: Па ово је подне, забога, није јутро" (Поповић 2001: 18). У истом маниру одређено је и драмско време у драми „Сабља димискија”, где је у дидаскалији испод пописа ликова записано: „Догађа се у Србији, после једног од многих ратова” (Поповић 2001: 137). Код оба писца време је релативизовано до апсурда, с том разликом што се оно код Јонеска креће у оба смера, те је тиме акценат у потпуности стављен на бесмисао времена као категорије. Код Поповића, нарочито у драми „Сабља димискија”, време је безлично и његово евентуално протицање нема никаквог значаја.

С друге стране, простор је, увек конкретан и у својству карактеризације јунака, што је поступак какав познаје и класична драмска форма. Простор драме „Столице”, који је скучен простор, окружен водом, метафора је психичког стања Старца и Старице. Код Поповића, отворени, широки простор парка у драми „љубинко и Десанка”, као и простор кафане у драми „Сабља димискија” део је конституисања драмског света. Драмски простор код Поповића сугерише маргиналност друштвене средине која се јавља у драмском тексту, указује на одсуство интимности и безличност карактеристичну за свет о коме је реч.

У овом тексту осветлили смо основне одлике драмске форме код Ежена Јонеска и Александра Поповића. Уз анализиране елементе који осветљавају драмску форму, било би значајно у оквиру ове теме истражити и осветлити концепцију и начин карактеризације лика у делима Ежена Јонеска и Александра Поповића. Поред тога остаје отворено и питање варијације на драмску форму коју су ови писци створили у својој првој стваралачкој фази драмских текстова, а која се у њиховим каснијим радовима у неким сегментима мењала. 


\section{ИЗВОРИ}

Јонеско 1997: E. Jonesko, Pozorište, Sabrana dela, Beograd: Paidea.

Поповић 2001: A. Popović, Drame, Beograd: Verzalpres, Vojnoizdavački zavod.

\section{ЛИТЕРАТУРА}

Дејвс 2015: Dž. M. Dejvs, Šta je farsa, u: Teorija dramskih žanrova, pr. S. Jovanov, Novi Sad: Pozorišni muzej Vojovodine, 322-338.

Жакар 1981: Е. Жакар, Композиција и њене технике (Јонеско, Адамов, Бекет), у: Модерна теорија драме, пр. М. Миочиновић, Београд: Нолит, 400-411.

Жакар 1997: E. Žakar, U traganju za Joneskom, u: Pozorište, Sabrana dela, Beograd: Paidea, 7-34.

Јонеско 1966: E. Ionesco, Notes et contre-notes, Paris: Gallimard.

Катанић-Бакаршић 2013: M. Katanić-Bakaršić, Stilistika dramskog diskursa, Sarajevo: IKD „University press”.

Миочиновић 1975: М. Миочиновић, Сценска игра Александра Поповића, у: Есеји о драми, Београд: Вук Караџић, 95-123.

Миочиновић 1990: М. Miočinović, Pozorište i giljotina, Sarajevo: Svjetlost.

Петковић 1998: Д. Петковић, Комедиографија Александра Поповића и француска драмска авангарда, Ниш: Филозофски факултет.

Пфистер 1998: M. Pfister, Drama: teorija i analiza, Zagreb: Hrvatski centar ITI.

Себије 1910: T. Sebillet, Art poetique françoys, Paris: Société nocvslle de librairie et d'édition.

Ћирилов 1997: J. Ćirilov, Susret Beograda sa Joneskom, u: E. Jonesko, Pozorište, Sabrana dela, Beograd: Paidea, 1233-1236.

Livija D. Ekmečić

\section{THE INFLUENCE OF THE DRAMATIC FORM OF EUGÈNE IONESCO ON THE DRAMATIC FORM IN THE WORK OF ALEKSANDAR POPOVIĆ}

\section{Summary}

The influence of the dramaturgy of Eugène Ionesco on the dramaturgy of Aleksandar Popović is very complex and multilayered. That is the reason why this study will focus on only one sphere of that influence, it being the dramatic form. In the first part of the research, the characteristics of Ionesco's dramatic form will be indicated, while the second part of this paper will be devoted to those elements of the dramatic form in the work of Aleksandar Popović shaped under the influence of Ionesco's dramaturgy. In that way, the intertextual relations of the Serbian and French writer will be illuminated within the framework of a specific dramatic element. 